\title{
Morphological variation in Staurastrum rotula (Zygnemaphyceae, Desmidiales) in the deepest natural Brazilian lake: essence or accident?
}

\author{
Barbosa, LG. ${ }^{a *}$, Araujo, GJM. ${ }^{a}$, Barbosa, FAR. ${ }^{b}$ and Bicudo, CEM. ${ }^{c}$ \\ aPlant Technology and Environmental Sciences Department, Center of Agrarian Sciences, Federal University of Paraíba - UFPB, \\ Campus II, Rodovia BR 079, Km12, CEP 58397-000, Areia, PB, Brazil

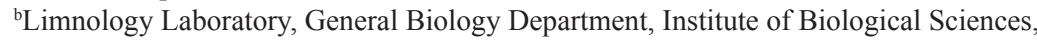 \\ Federal University of Minas Gerais - UFMG, Av. Antônio Carlos, 6627, Pampulha, \\ CP 486, CEP 30161-970, Belo Horizonte, MG, Brazil \\ ${ }^{\mathrm{c}}$ Center for Ecology Research, Institute of Botany, Av. Miguel Stéfano, 3687, Água Funda, \\ CP 3005, CEP 01061-970, São Paulo, SP, Brazil \\ *e-mail: lucianabarbosa@cca.ufpb.br
}

Received November 22, 2012 - Accepted March 1, 2013 - Distributed May 31, 2014

(With 28 figures)

\begin{abstract}
For many decades, polymorphism and its consequences have only been studied from the taxonomic point of view. Presently, interest has switched to the environmental causes of morphological variation and its consequences in the form and essence of the species. This study aimed at evaluating desmids morphological modifications of Staurastrum rotula Nordstedt during inter-annual succession patterns in two warm monomitic tropical lakes: Dom Helvécio (1945'-

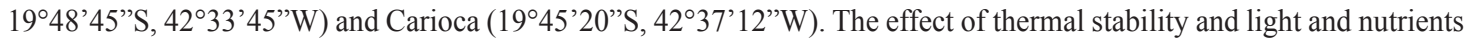
availability was based on samples collected monthly from January 2002 to December 2006 compared the morphological modifications. Results indicated that morphological variation, asexual reproduction, theratological forms, mucilaginous envelope and fungal infection were highest in Lake Dom Helvécio and coincided with the biomass increase of species with complex morphology between September and March (stratification period). The Zmix oscillation, wind and rainfall occurring at the end of the mixing period and beginning of the stratification were suggested as autochthonous and allochthonous disturbance agents, respectively, identified as inducers of asexual reproduction and consequently of the morphological variation. It was suggested that incidence of parasitism may act as a potential controlling agent for the Staurastrum rotula population size. It was concluded that morphological variation represents accidents in the original form, i.e. in the desmid species essence, promoting the existence of ecoforms, not of new infraspecific taxa.
\end{abstract}

Keywords: desmid, intermediate disturbance, morphology, temperature.

\section{Variação morfológica em Staurastrum rotula (Zygnemaphyceae, Desmidiales) em um lago natural profundo do Brasil: essência ou acidente?}

\section{Resumo}

Por muitas décadas, o polimorfismo e suas conseqüências foram estudados apenas do ponto de vista taxonômico. Atualmente, o interesse se volta para as causas ambientais das variações morfológicas e suas consequencias na forma e essência da espécie. O estudo teve como objetivo avaliar as modificações morfológicas de Staurastrum rotula Nordstedt durante padrões inter-anuais de sucessão em dois lagos tropicais monomíticos-quentes: Dom Helvécio (1945'-1948'45'S, $\left.42^{\circ} 33^{\prime} 45^{\prime} \mathrm{W}\right)$ e Carioca $\left(19^{\circ} 45^{\prime} 20^{\circ}\right.$ 'S, $\left.42^{\circ} 37^{\prime} 12^{\prime} \mathrm{W}\right)$. O efeito da estabilidade térmica e potenciais distúrbios sobre as modificações morfológicas foi baseado em amostras coletadas mensalmente de janeiro de 2002 a dezembro de 2006. Os resultados indicaram que a variação morfológica, a reprodução assexuada, as formas teratológicas, envelope mucilaginoso e infecção fúngica foram maiores no Lago Dom Helvécio e coincidiu com o aumento da biomassa de espécies com morfologia complexa entre setembro e março (período de estratificação). A oscilação Zmix, vento e chuva ocorrentes entre o final do período de mistura e início da estratificação foram sugeridos como agentes perturbadores autóctones e alóctones, respectivamente, identificados como indutores de reprodução assexuada e, consequentemente, de variação morfológica. Foi sugerido que a incidência de parasitismo atua no controle do tamanho da população Staurastrum rotula. A variação morfológica, portanto, representa acidentes na forma original, ou seja, na essência das desmídias, promovendo a existência de ecoformas, não de novos táxons infraespecíficos.

Palavras-chave: desmídias, distúrbio intermediário, morfologia, temperature. 


\section{Introduction}

Considered an important tool for aquatic ecosystems conservation and management processes (Coesel et al., 1978; Coesel, 2001), desmids have cosmopolitan distribution, enormous environmental plasticity (Brook, 1981) and a high degree of polymorphism (Bicudo and Sormus, 1972). Playfair (1908) had already mentioned that desmids are polymorphic and that $90-95 \%$ of all at that time described species would be nothing but morphological expressions of the remaining 5-10\%. According to Bicudo (1988), Playfair's (1908) numbers are obviously exaggerated, but the idea of a considerable percentage of all described desmid species be nothing but morphological expressions is absolutely valid.

The most important factor towards a correct taxonomical identification of algae is the careful detailed knowledge of its morphological variability, much more when desmids are concerned since the species concept in the group is presently so very bad defined (Kouwets, 2008). 'Species' identification clearly depends on its external cell morphology and, somewhat occasionally, also on the plastid characteristics and the zygospore morphology (Brook, 1981).

Description of any species is not inert. On the contrary, it changes always a new variety is described (Kouwets, 2008). The question is, however, up to what extent morphological variation induced by environmental changes allows identification of new species, varieties or taxonomic forms? For Aristotle, 'essence' includes, on the one hand, everything that characterises the individual creature substratum, i.e. everything that the individual creature is by itself and that defines its identity. 'Accident' includes, on the other hand, every characteristic that is added to the individual creature, but that despite being part of its constitution does not define it, being simply considered a secondary aspect of its existence. It may or not exist, independent of the individual creature be what it really is. Consequently, a species shall be defined just and only by characteristics that are inherent to their 'essence'. Morphological characteristics subjected to constant modification need to be carefully studied and identified, and morphological 'accidents' shall not be used for the proposition of new species and infraspecific taxa in desmids.

Morphological and physiological modifications of planktonic algae are nothing but adaptation mechanisms for its life in suspension (Reynolds, 1984), protection against herbivory (Wiltshire et al., 2003) or response to environment contrasts (Morales et al., 2002). Desmid's morphological complexity is induced by evolution processes (Kouwets, 2008). Furthermore, it was observed that changes in growth conditions may result in greater or lesser morphological differences, even between mother and daughter semicells, that will misrepresent the original cell symmetry (Kouwets, 2008) resulting in great polymorphism, even if a single species is considered. Consequently, the life history at population level must be constructed by observing the transitional forms and the relationship among the morphological expressions (Playfair, 1910).
Present study aimed at testing the hypothesis that desmids present morphological variation dependent on the environment abiotic conditions mainly associated to temperature, and that such structural alterations constitute, with high frequency, 'accidents' and do not identify new species, varieties or taxonomic forms, but simply phenotypic modifications or ecoforms.

\section{Material and Methods}

\subsection{Study area}

The Rio Doce State Park is located about in the centre of the Rio Doce Lake District, southeast Brazil (19²9'S; $42^{\circ} 28^{\prime} \mathrm{W}$ ) (De Meis and Tundisi, 1997). Located in a humid tropical forest area, $20 \mathrm{~m}$ below the river Doce level (De Meis and Tundisi, 1997), the ecology of the two lakes is closely related to the geomorphological processes that gave origin to them (De Meis and Tundisi, 1986). A dominant form among the Park lakes is the dendritic (identification by aerial photograph), the circular form of Lake Carioca being less common (Tundisi and Mussarra, 1986). Among the lakes and ponds of the Park lacustrine system, Lake Carioca is a shallow, more or less roundshaped, rich in nutrients system (Barbosa and Tundisi, 1980), with a surface area of $0.14 \mathrm{~km}^{2}$ and maximum depth of $11.8 \mathrm{~m}$. Lake Dom Helvécio is, in contrast, a system that is deep, oligotrophic, dendritic in shape, with a surface area of $5.27 \mathrm{~km}^{2}$ and maximum depth of $39.2 \mathrm{~m}$ (Bezerra-Neto and Pinto-Coelho, 2008). Both are monomitic, warm, stratified systems between September and April, and basically isothermal from May to August (Henry and Barbosa, 1989).

\subsection{Laboratory analysis}

Water temperature, dissolved oxygen, electric conductivity and $\mathrm{pH}$ profiles were measured 'in situ' with a multiparameter probe (Horiba sensor model U-22) at regular $0.50 \mathrm{~m}$ intervals. The mixing zone $\left(\mathrm{Z}_{\text {mix }}\right)$ was identified according to Reynolds (1984). The euphotic zone $\left(\mathrm{Z}_{\text {eu }}\right)$ :mixing zone $\left(\mathrm{Z}_{\text {mix }}\right)$ ratio was used as an index for light availability in the mixing zone (Jensen et al., 1994). Stability (S) was calculated using Idso's (1973) equation. The mixing zone $\left(Z_{\text {mix }}\right)$ was calculated on the basis of the water temperature differences, considering the layer above in which the temperature gradient first exceeded $0.2^{\circ} \mathrm{C}$ (Coche, 1974).

Desmids were collected both at the littoral and limnetic region of the Dom Helvécio and Carioca lakes. Monthly samples were gathered during a five-year period (2002-2006), with emphasis on the months of February, May, July and September. These months were chosen according to the thermal regimen of the two lakes, to include stratification (February), intermediate between stratification and mixing (May and September) and mixing (July) periods. Samples were immediately fixed after collection and preserved in $3-4 \%$ formalin water solution (Bicudo, 1990).

Due to the high incidence of polymorphism, taxonomic identification of algae was based on population sample 
analysis, i.e. on the examination of about 100 individual specimens of each species, variety or taxonomic form in the community or on as many specimens was needed to not find any different morphological expression in the preparation. Eventual differences in the shape of individual specimens identified (shape of semicell, proportion between length and maximum breadth linear cell dimensions, and angular processes length) were considered during the taxonomic identification process. In brief, all diacritic, metric and meristic morphological characteristics of the vegetative part of life history were considered.

Among the characteristics studied, cell and semicell shape, cell maximum length and semicell breadth (with and without angular processes), angular processes length, cell wall facial decoration and texture deserved special attention. Observation of asexual reproduction (cell division), morphological expressions, presence of mucilaginous envelope and parasitism by fungi was made from a 10 preparations average of each sampling unit, which was examined under a Zeiss (Axioskop 2) regular microscope, with a camera lucida and digital metric ocular adapted to the optical system of microscope. Frequency of occurrence of ecoforms followed the criterion below: Constant (CT): ecoform present in at least $80 \%$ of preparations examined; Common (CM): ecoform present in $50-80 \%$ of preparations examined, and Rare (R): ecoform present in less than 50\% of preparations examined. The size was evaluated from the values of the maximum linear dimension (MLD): Class $1(<10 \mathrm{~mm}$ ), class 2 (between 11 and $20 \mathrm{~mm}$ ), class 3: between 21 and $50 \mathrm{~mm}$, and class 4: $>50 \mathrm{~mm}$.

Analysis of environmental factors of the two lakes, $Z_{\text {mix }}$ and $Z_{\text {mix }} / Z_{\text {eu }}$ ratio led to selection of descriptors, i.e. of some robust variables that would indicate changes and fluctuations in the morphology of the algae over the five years series of the present study (Naselli-Flores and Barone, 2000; Naselli-Flores and Barone, 2007).
Desmids were studied according to their morphological complexity and divided into simple (forms without angular processes or spines: Cosmarium and Euastrum), complex (forms with angular processes or spines: Staurastrum and Staurodesmus) and cylindrical attenuate forms (elongate and/ or filamentous forms: Closterium and Pleurotaenium). In the case of the simple forms, both unicelular (Cosmarium) and isodiametric fragments morphologically similar to Cosmarium were considered. The origin of such fragments is associated to the dissociation of filaments such as those of Teilingia and Spondylosium.

\section{Results}

\subsection{Physical and chemical variables: spatial segregation and recurrent seasonal differences}

Winds measured for the area were classified from breeze $\left(<11 \mathrm{~m} \mathrm{~s}^{-1}\right)$ to tempest (maximum values $27.5 \mathrm{~m} \mathrm{~s}^{-1}$ ) that occurred towards the end of the mixing period and during the stratification one (September-April). Wind speed measured at the surface of systems varied between 0.3 and $8.5 \mathrm{~m} \mathrm{~s}^{-1}$ at Lake Carioca and between 0.2 and $8.9 \mathrm{~m} \mathrm{~s}^{-1}$ at Lake Dom Helvécio (minimum and maximum values, respectively). The greatest precipitation values (mm) were measured between November and March, identifying a rainy period, the greatest values always documented in December, except for 2003 when it was measured in November (219 mm) (Table 1). Epilimnion extension or $\mathrm{Z}_{\text {mix }}$ varied during the stratification period from 1.5 a $6.5 \mathrm{~m}$ at Lake Carioca and from 5 to $12 \mathrm{~m}$ at Dom Helvécio, and progressively increased during the transition rainy-dry period. During the mixing period (May-September), an isothermal episode was identified for both lakes. Thermocline varied between 4 and $14 \mathrm{~m}$ deep at Lake Dom Helvécio and 2 and $8 \mathrm{~m}$ at the Carioca.

Table 1. Climatic features provided by the Meteorological Station of the Instituto Mineiro de Gestão das Águas (10 km from the Rio Doce State Park), for the period 2002-2006.

\begin{tabular}{lccccc}
\hline \multicolumn{1}{c}{ PERIOD } & $\begin{array}{c}\text { Rain } \\
\text { precipitation } \\
(\mathbf{m m})\end{array}$ & $\begin{array}{c}\text { Air } \\
\text { temperature } \\
\left({ }^{\circ} \mathbf{C}\right)\end{array}$ & $\begin{array}{c}\text { Air relative } \\
\text { humidity } \mathbf{( \% )}\end{array}$ & $\begin{array}{c}\text { Wind speed } \\
\left(\mathbf{m ~ s}^{-1}\right)\end{array}$ & $\begin{array}{c}\text { Solar } \\
\text { radiation } \\
\left(\mathbf{M J ~ m}^{\mathbf{2}}\right)\end{array}$ \\
\hline Stratification (n=280) & 101.5 & 25.3 & 83.4 & 13.3 & 17.8 \\
Average & 75.5 & 0.94 & 8.5 & 7.3 & 2.9 \\
Standard deviation (SD) & 75.3 & 3.73 & 10.1 & 55.0 & 16.5 \\
Variation Coeficcient (\%) & 249.5 & 28.3 & 94.5 & 27.5 & 23.5 \\
Maximum & 0 & 23.3 & 63.0 & 6.4 & 9.6 \\
Minimum & & & & 20.2 & 13.2 \\
Mixing (n=200) & 4.0 & 21.4 & 86.7 & 6.3 & 1.6 \\
Average & 6.85 & 1.20 & 7.2 & 36.4 & 12.6 \\
Standard deviation (SD) & 172.1 & 5.6 & 94.1 & 27.1 & 16.0 \\
Variation Coeficcient (\%) & 25.2 & 23.7 & 74.3 & 12.2 & 10.1 \\
Maximum & 0 & 19.7 & & & \\
Minimum & & & & & \\
\hline
\end{tabular}


Dissolved oxygen (DO) patterns had its temporal distribution dynamics affected by the thermal regimen in both lakes. The first phase corresponded to the thermal stratification (January-April and October-December), with DO super saturation being observed at the epilimnion $(>100 \%)$ and sub saturation $(<50 \%)$ below the thermocline. Hypolimnetic anoxia also occurred, a characteristic of the period. The second phase corresponded to the mixing period (May-September), when an orthograd DO profile was identified.

Greatest water transparency values (variation range 2-4 $\mathrm{m}$ ) and those of least light attenuation (variation range 0.56-0.68) were measured at Lake Dom Helvécio. Lake Carioca presented, in turn, the least water transparency values (variation range $0.5-2.5 \mathrm{~m}$ ) and the greatest light attenuation ones (variation range 0.85-3.4). Regarding the optical structure, two distinct phases were observed associated to the thermal regimen of the two lakes: (1) a phase with greater light availability in January-April and September-December and (2) another one with less water transparency and consequent numerical reduction of $\mathrm{Z}_{\mathrm{eu}}$ $/ Z_{\text {mix }}$ in May-August. Carioca and Dom Helvécio lakes showed the same variation range for their $\mathrm{Z}_{\mathrm{eu}} / \mathrm{Z}_{\text {mix }}$ ratio, i.e. $0.9<\mathrm{Z}_{\mathrm{eu}} / \mathrm{Z}_{\text {mix }}<1.8$.
The trophic status of the two lakes, with maximum values were detected during the period May-December, which were situated at the border line between mesotrophic and eutrophic $(44<$ IET $<54)$ for both lakes.

The mechanisms governing chemical dynamics and thermal stability of the reservoir in the studied period were analysed in detail in Barbosa et al. (2012a).

\subsection{Biological characteristics: mucilaginous sheath, fungi infestation and asexual reproduction}

Presence of mucilaginous sheath was registered (Figure 7), however, rarely and with a less fibrous texture than that of the simple forms (Cosmarium). Despite its presence during the entire study period, the greatest number of species with mucilaginous sheath was registered between September and December. At Lake Carioca, however, the presence of species with sheath was rare and restricted to Cosmarium specimens.

Staurastrum rotula was very much subjected to infestation by chitridiacean fungi (Chytridiomycetes), the development of epidemic conditions (>90\%) identified during the months of maximum development of the species at Lake Dom Helvécio, between September and February (Figures 4-8). Maximum epidemics was recurrently

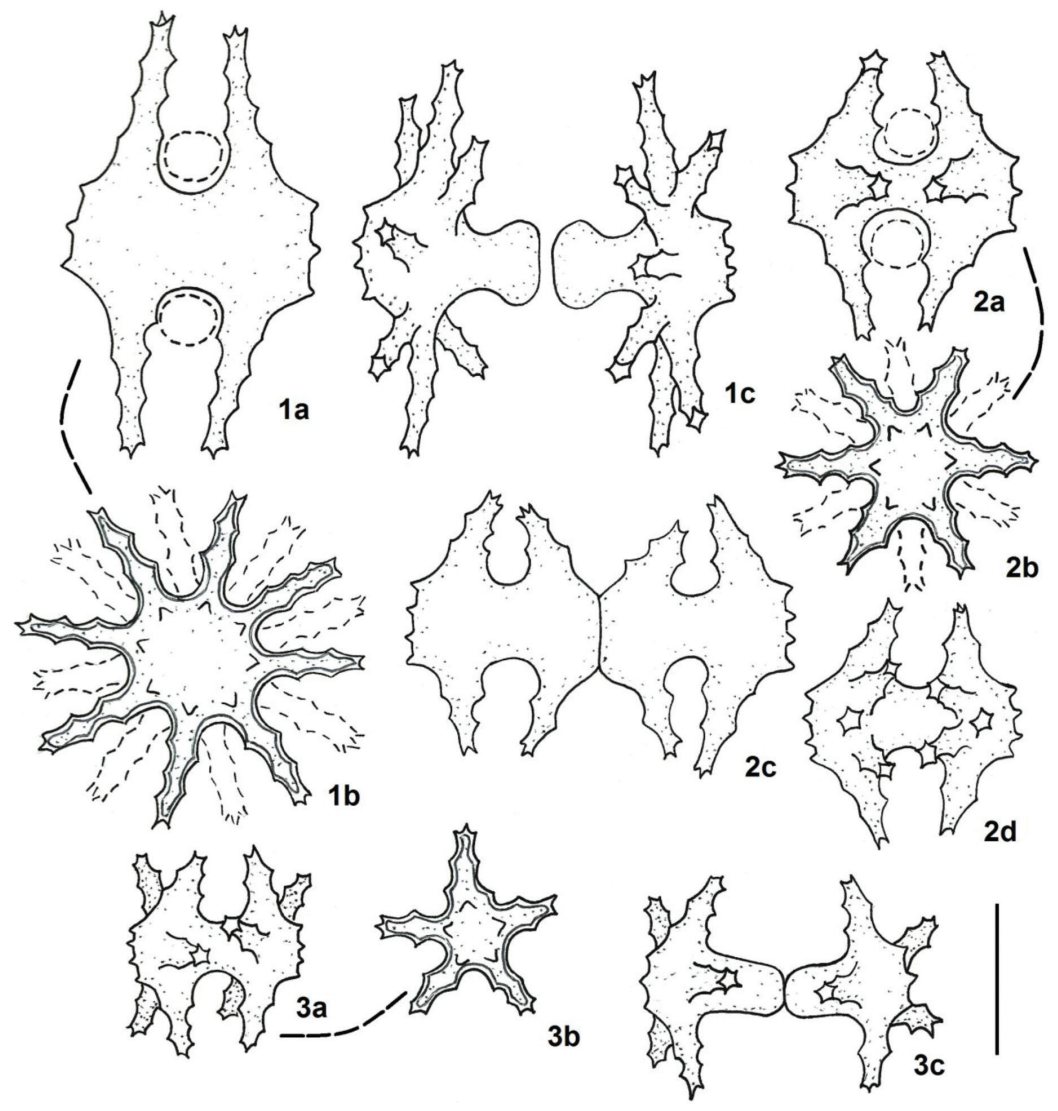

Figures 1-3. Staurastrum rotula Nordstedt. 1. Morphotype 1; a. typical form; b. lateral view with 8 processes; c. form undergoing cell division. 2. Morphotype 2; a. typical form; b. lateral view with 6 processes; c. form in the final stage of cell division; d. form with 8 processes. 3. Morphotype 3; a. typical form; b. lateral view with 5 processes; c. form undergoing cell division. Bar $=20 \mathrm{~mm}$. 


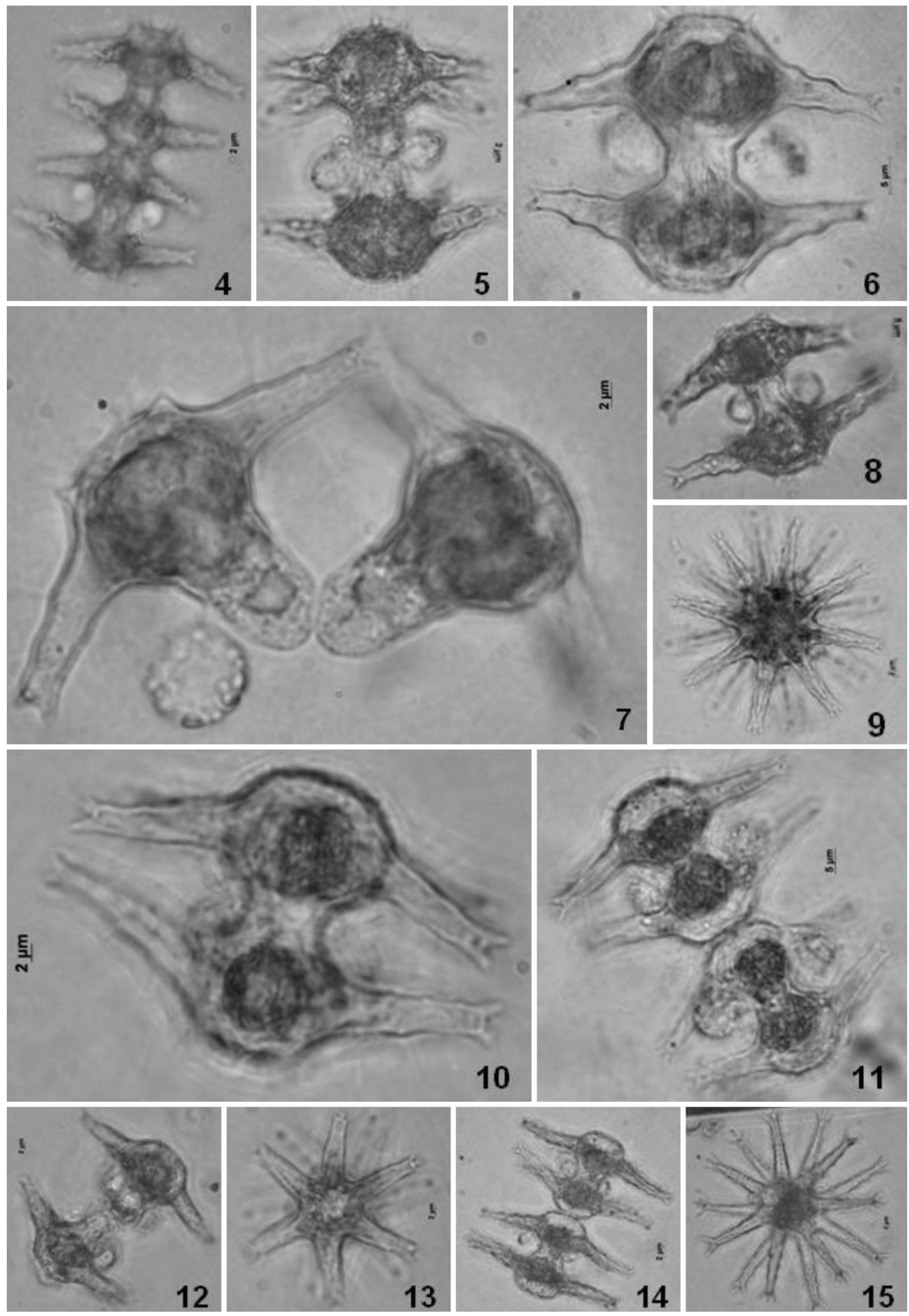

Figures 4-15. Staurastrum rotula Nordstedt, different morphological expressions from Lake Dom Helvécio. 
registered in September. Specimens with greater MLD presented greater infestation by fungi incidence than those with lesser MLD (<40 mm). At Lake Carioca, there was no register of epidemic infestation and the incidence of infection by fungi was much lower.

The greatest occurrence of asexual reproduction (cell division) was observed during the September-April period, with the maximum detected in September at Lake Dom
Helvécio (Figure 5). Great asexual reproduction rates induced formation of aberrant or theratological forms in great proportions (Figures 8, 16, 17, 22). Acceleration of the cell division process led to not yet totally morphologically developed new semicells to start a new division, giving origin to forms that deviate to what is more or less an extension from the original pattern, which are presently named aberrant.
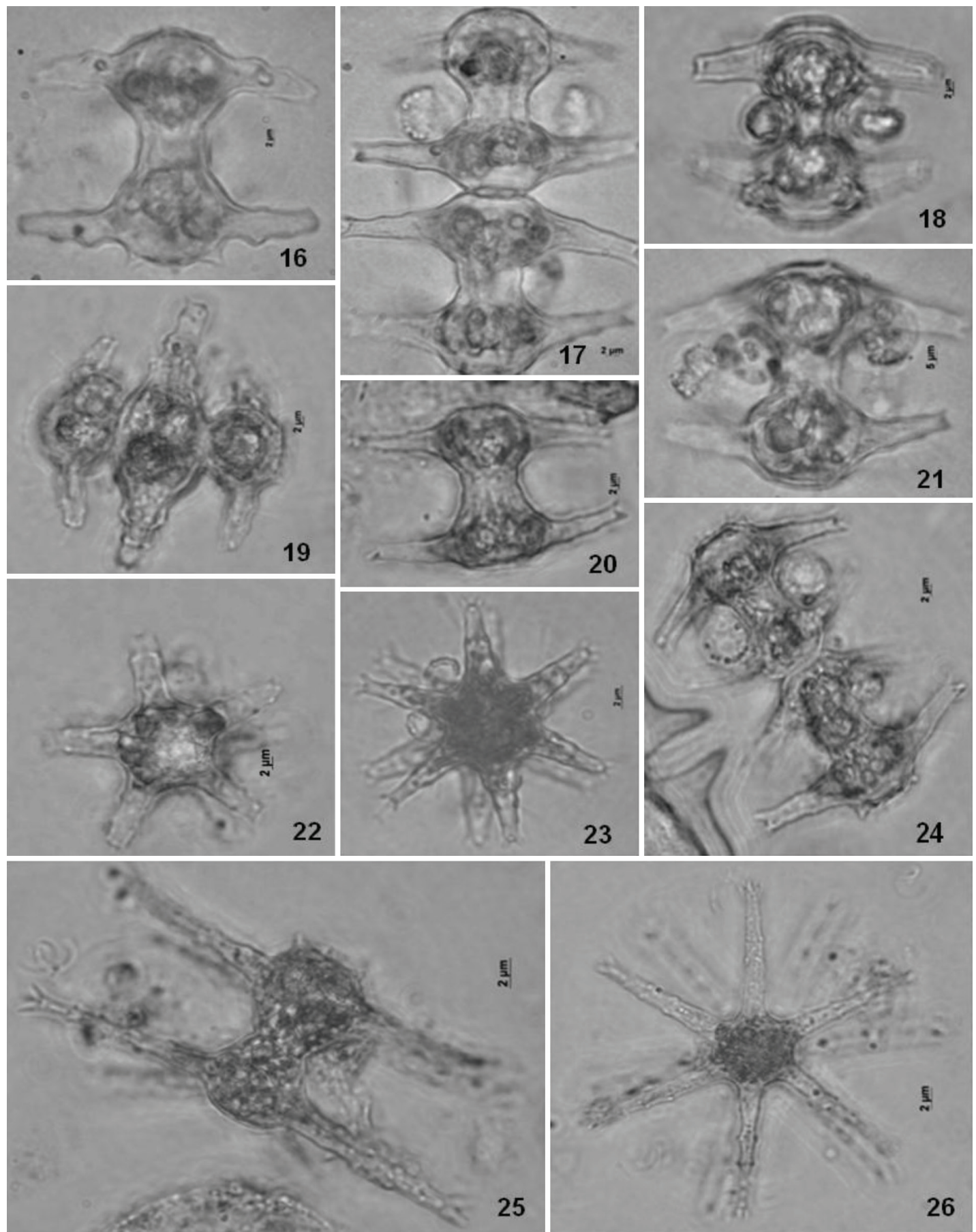

Figures 16-26. Staurastrum rotula Nordstedt, different morphological expressions from Lake Carioca. 
(a)
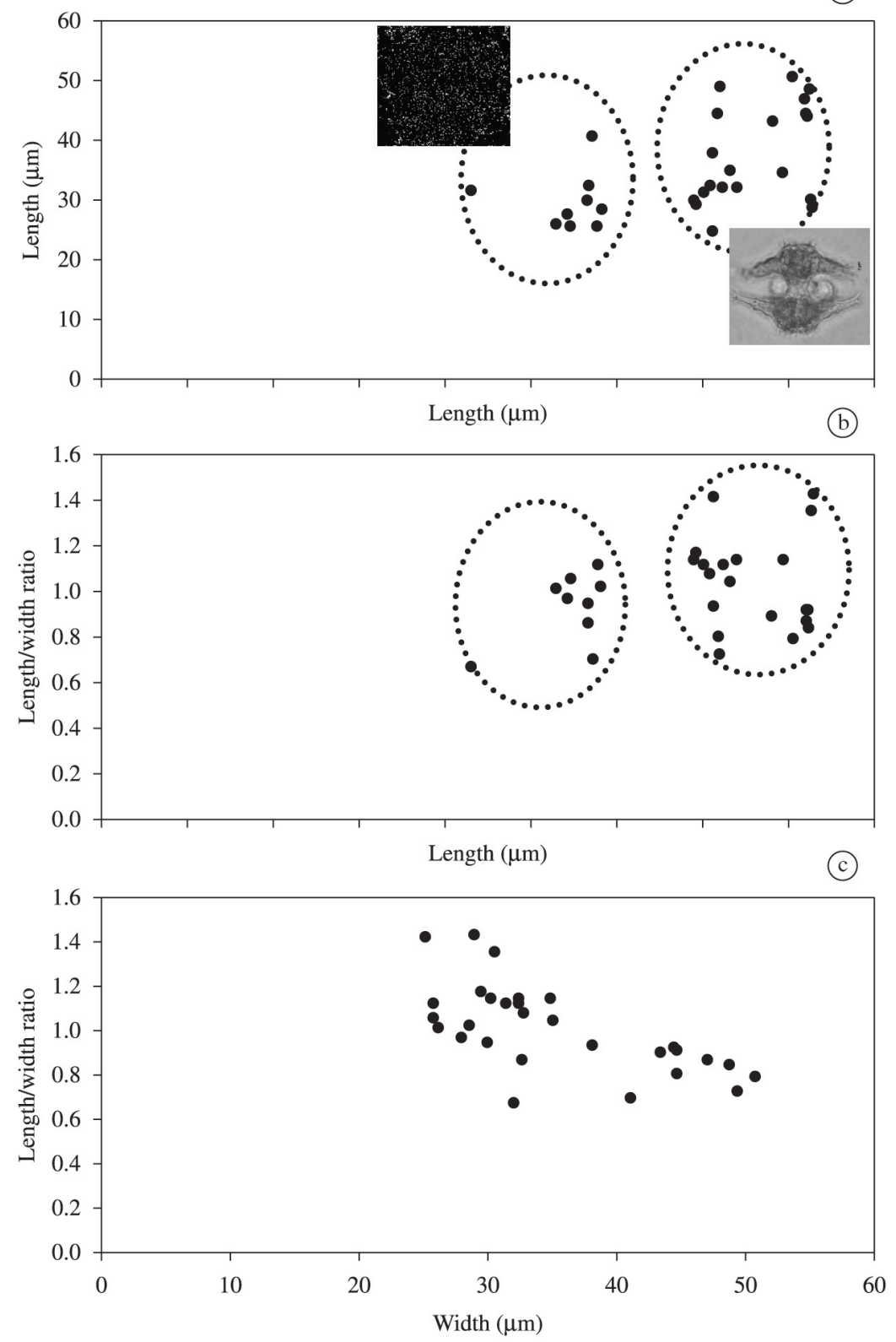

Figure 27. Alometric relationships of Staurastrum rotula Nordstedt. (a) cell length $\mathrm{x}$ cell breadth, (b) cell length:cell breadth $\mathrm{x}$ cell breadth and (c) cell length $\mathrm{x}$ cell breadth and cell breadth. Highlighted,for morphotypes 1 and 2 populations.

\subsection{Morphological variation}

Cell length $21.5-41.5 \mathrm{~mm}$, cell breadth $25-50.8 \mathrm{~mm}$, isthmus breadth 9-9.2 $\mathrm{mm}$; processes length 10.9-28.9 mm, processes breadth 3-6.6 $\mathrm{mm}$.

At Lake Dom Helvécio (Figures 4-15), the great majority of $S$. rotula populations presented a wide morphological variation, in the number of angular processes, shape of semicells, shape of the semicell apical margin and length of angular processes and that of the semicell apical view being the most relevant one. Distinct morphotypes were observed for some of these presented semicells with 8 (seldom 7) long, horizontally disposed processes (morphotype 1, Figures 1a-c); some others presented semicells with 6 short, convergent processes (morphotype 2, Figures 2a-d); still others presented semicells with 5 short, slightly convergent processes (morphotype 3, Figures 3a-c); and finally others presented semicells with 6 long, horizontally disposed processes (morphotype 4, Figures 25, 26). Differences in the length of processes were observed even in one single individual specimen.

All four morphotypes were documented throughout the entire study period, especially in September. During all other months, however, morphotype 2 prevailed, all 


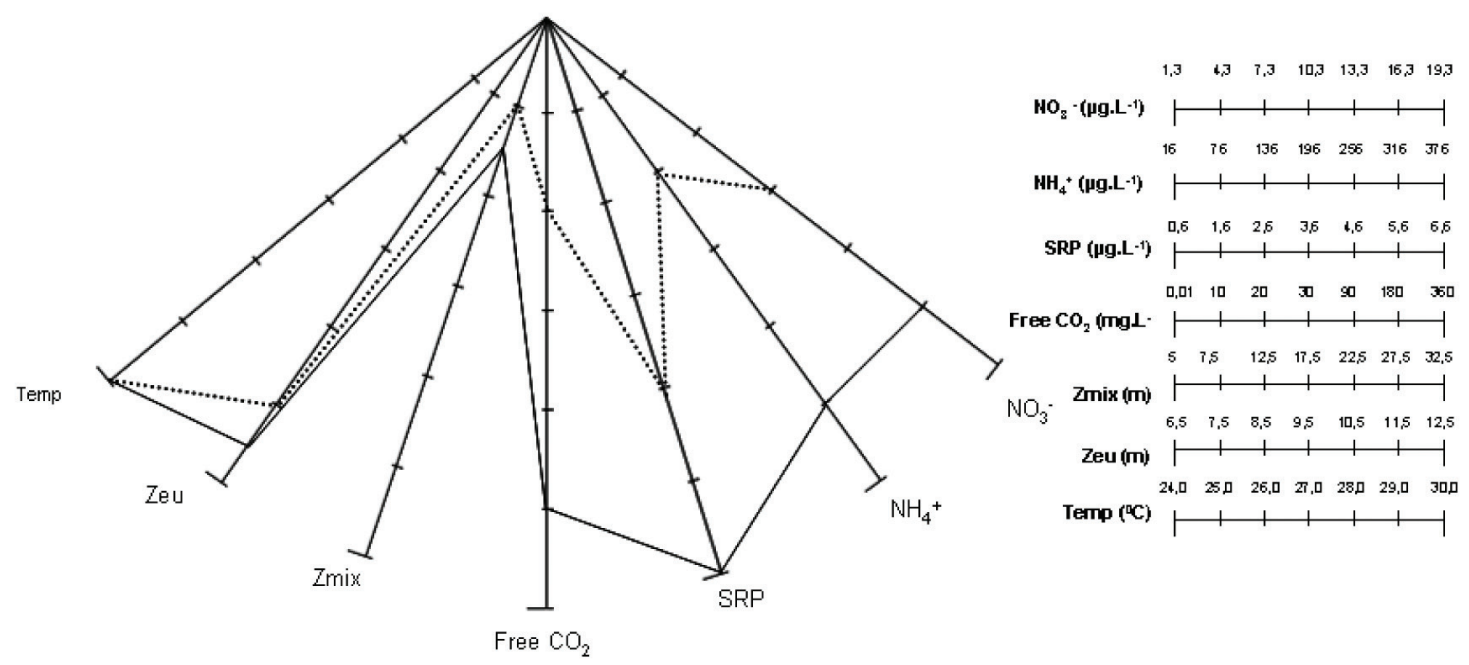

Figure 28. Habitat model summarising Staurastrum tetracerum (Kützing) Ralfs ex Ralfs var. tetracerum f. tetracerum and $S$. laeve Ralfs (dotted line) and Staurastrum rotula Nordstedt (continuous line) attributes during the second annual stratification (September-December; $\mathrm{n}=80$ ). Minimum values depart from the centre of graph. Habitat models of $S$. rotula ecoforms overlap. Legends: Temp = Temperature; $\mathrm{Zeu}=$ Euphotic zone; $\mathrm{Zmix}=$ Mixing zone; Free $\mathrm{CO}_{2}$; $\mathrm{SRP}=$ soluble reactive phosphorus; Forms of dissolved nitrogen: $\mathrm{NH}_{4}=$ Ammonium; $\mathrm{NO}_{3}=$ Nitrate.

other ones occurring just sporadically, classified as constant (CT). Forms with 5-8 angles in the apical view were recorded, the rarest one being the 7 -angled. Protuberances, undulations and differences in the process length were registered for all morphotypes. It was also observed that some morphotypes showed some overlapping. Separation was mainly based on the number and size of angular processes. The first group included individual specimens with semicells with (7-)8 long processes together with others with 6 equally long processes (morphotypes 1 and 4 ). The second group included individual specimens with semicells with 6 comparatively shorter processes together with others with equally short 5 processes (morphotypes 2 and 3) (Figure 27).

At Lake Carioca (Figures 16-26), only two morphotypes were identified, with prevalence of that with 6 comparatively long processes (morphotype 4) (Figures 25, 26). The other morphotype showed 6 short processes (morphotype 2) (Figures 16-24), and both were considered rare (R).

Figure 28 summarises $S$. tetracerum (Kützing) Ralfs ex Ralfs var. tetracerum f. tetracerum, $S$. laeve Ralfs and Staurastrum rotula to environment characteristics and ecological ranges that allowed their coexistence in the Lake Dom Helvécio.

\section{Discussion}

\subsection{Mucilaginous sheath and fungi infestation}

The occurrence of a great number of individual specimens with mucilaginous sheath occurred in September and December, but it is not possible to state that sheath production is an opportunistic event (Reynolds, 2006).
However, its function towards reducing cell density and propitiating a microclimate for cell division are hypothesis to be considered for both studied systems. The selective permeability of mucilaginous envelopes might provide a defense against the toxic cations uptake in the acidic environment tolerated by some desmids (Coesel, 1994).

A possible factor during the host selection by zoosporic fungi is the cell size, but this possibility was never studied in detail (Kagami et al., 2007). However, a positive correlation between the fungus cell size and that of the host was already documented (Holfeld, 1998). Staurastrum rotula is a highly sensitive species to fungi infestation, and the latter always occur at population level during periods of high algal density, as already registered for Staurastrum longipes (Nordstedt) Teiling in Shearwater, England (Sen, 1988), with a subsequent decrease of the algal population density. In the present study, infestation occurred in all four morphotypes, however, much greater in representative specimens of morphotypes 1 and 4. Larger size cells are more susceptible to parasites than the smaller size ones due to having more resources to offer and favour parasite fecundity (Kagami et al., 2007). Furthermore, the relationship between parasite and host is highly specific in desmids (Holfeld, 1998; Holfeld, 2000).

Staurastrum rotula population infestation reached approximately $90 \%$ of examined individual specimens in September, and was recurrent during the entire study period. Effects of such infestation on the phytoplankton population in natural lakes were collected by Kagami et al. (2007). Decrease in population size and density, replacement of dominant species by other ones (Canter and Lund, 1951) 
and competition among species subdominant (Canter and Lund, 1969) are well known.

Reduction of $S$. rotula population was observed from September on in terms of the specimen's density over the 5 years of present study. The quantitative expression is restricted to biomass $\left(\mathrm{mg} \mathrm{L}^{-1}\right)$, due to the high biovolume of its representative specimens $\left(8,532.2 \mathrm{~mm}^{3}\right)$ (Barbosa et al., 2012 b). In this regard, the hypothesis of $S$. rotula population control by parasites is highly feasible. Desmids infestation by fungi and its seasonal fluctuation may be explained by the very same environment factors that favour development of the alga, such as: temperature increase $\left(>25^{\circ} \mathrm{C}\right)$, light and nutrients availability increase and structural modifications in the $\mathrm{Z}_{\text {mix }}$ Simultaneous occurrence of environmental optima for parasites and hosts was registered by Van Donk and Ringelberg (1983) in population of diatoms, but never of desmids.

\subsection{Morphological variation in desmids: disturbance or a natural occurrence?}

Phenotypic variability is, 'a priori', a response to light and nutrient availability (Stoyneva et al., 2007), as well as to herbivory and system disturbance (Naselli-Flores and Barone, 2007). Special emphasis shall be put to the thermal regimen seasonal variation as the main determining factor for the distribution of resources such as light and nutrients in the water column, the morphological variation of algae being a reflex of the above mentioned variation (e.g. Naselli-Flores and Barone, 2007) and, at a micro scale, also of atelomixis as an intermediate disturbance agent.

In December 2002 at Lake Dom Helvécio, a high number of individual specimens were observed undergoing asexual reproduction during the morning, soon after heavy rain during the dawn. Allochthonous disturbance agents in the Lake Balaton (Hungary) indicated that sudden changes in the phytoplankton community structure may be a result of tempests occurring between five and 15 days after a drought period (Padisák et al., 1990). Jacobsen and Simonsen (1993) observed in a Danish lake that the incidence of winds above $>10 \mathrm{~m} \mathrm{~s}^{-1}$ and of precipitations at the end of July increased the algae mortality rate, breaking the lake stratification after a stagnation period. Thus, heavy rains occurrent during thermal stratification can be considered disturbances, promoting breaking of environmental stability and increased replication rate. In this condition, the cells do not reach maturity before a new morphological reproductive cycle favouring the morphological differentiation and generation of morphotypes in a process seasonal.

Small scale alterations verified in the Lake Dom Helvécio thermal structure between the end of the dry period (AugustSeptember) and beginning of the stratification one may be interpreted as autochthonous disturbance agents (e.g. atelomixis, $\mathrm{Z}_{\text {mix }}$ and structural modifications). Furthermore, there are allochthonous intermediate disturbance agents represented by the instant wind strokes $>10 \mathrm{~m} \mathrm{~s}^{-1}$, which influence the species life history. Consequently, there was a recurrent increase in the asexual reproduction rate as a strategy for the maintenance of the species. Acceleration of the cell division process led to not yet totally morphologically developed new semicells will start a new division, originating forms that deviate to a more or less extension from the original pattern, which are presently named aberrant.

The temperature and seasonal variation range plays an important role in the production of morphological variation in algae. Brandham (1964) investigated the effect of temperature on Staurastrum polymorphum Brébisson and concluded that the cell symmetry in apical view was intimately dependent on that factor, so that under low temperature dominated the 4-radiate form and under high temperature, the 3-radiate one. This identical fact was observed by Reynolds (1940) in natural population of Staurastrum chaetoceras (West et G.S. West) G.M. Sm., the 3-radiate forms dominating during the summer and the 2 -radiate ones in the fall, winter and spring. The increasing temperature in Dom Helvecio lake at the subsurface and the entire water column reached differences between 1.6 and $2{ }^{\circ} \mathrm{C}$ in August and September.

Structural modifications in the cell morphology occur mainly as a function of the algal adaptation to life in suspension. Brook (1959) registered a possible evolution trend in some Staurastrum species characterised by the elongation of the cell and angular processes and reduction in the cell ornamentation parallel to an increase in the adaptation to flotation.

The subaquatic light regimen may represent an important trigging factor for alterations in desmids. Coesel and Kooijman-Van Blokland (1991) registered in the field and unialgal culturing experiments [Closterium acutum (Kyngbye) Brébisson ex Ralfs var. variable (Lemmermann) Krieger, Closterium aciculare T. West, Staurastrum cingulum (West \& West) G. M. Smith e Cosmarium abbreviatum Raciborski] the presence of an optimal development range under experimental conditions using high temperature $\left(25-30{ }^{\circ} \mathrm{C}\right)$ and irradiance $\left(8,22-85 \mathrm{mE} \mathrm{m}^{-2} \mathrm{~s}^{-1}\right)$. Interspecific differences were also observed, however, with Closterium acutum presenting high growth rates (more than one duplication per day) under $30^{\circ} \mathrm{C}$ temperature and $85 \mathrm{mE}$ $\mathrm{m}^{-2} \mathrm{~s}^{-1}$ irradiance, whereas Closterium aciculare presented its optimum growth under comparatively lower temperature $\left(25-28{ }^{\circ} \mathrm{C}\right)$ and high irradiance $\left(22-85 \mathrm{mE} \mathrm{m}^{-2} \mathrm{~s}^{-1}\right)$, with theratological forms observed under high temperature $\left(30{ }^{\circ} \mathrm{C}\right)$ conditions.

Considering an evolution approach, it was repeatedly demonstrated that natural selection favours establishment of plastic genotypes, because the environment unpredictability somewhat tends to suppress phenotypes (Scheiner, 1998). In other words, plasticity allows the genotype a capacity of exhibiting a great number of phenotypes in order to face the environment variation (Fordyce, 2006). It must be stressed, however, the importance of the environment variability produced by stratification for the coexistence of species with distinct morphologies (Naselli-Flores and Barone, 2007). 
Finally, one must also stress after considering the Aristotelian definitions of 'essence' and 'accident' that morphological modifications represent, in fact, 'accidents' of the original form, since they are phenotypical variations of species with great phenotypic plasticity and, thus, are not enough to define nor subdivide them in new specific and infraspecific taxa. On the contrary, they must be evaluated and explained using the concept of ecoform or morphotype.

\section{References}

BARBOSA, FAR. and TUNDISI, JG., 1980. Primary production of phytoplankton and environmental characteristics of a shallow Quaternary lake at Eastern Brazil. Archiv fuer Hydrobiologie, vol. 90 , no. 2, p. 139-161.

BARBOSA, LG., BARBOSA. and BICUDO, CEM., 2012a. Inter-annual chemical stratification in Brazilian natural lakes: meromixis and hypolimnetic memory. Acta Limnologica Brasiliensia, vol. 24, no. 2, p. 127-139. http://dx.doi.org/10.1590/S2179975X2012005000032.

BARBOSA, LGB., BARBOSA, FAR. and BICUDO, CEM., $2012 \mathrm{~b}$. Adaptive strategies of desmids in two tropical monomictic lakes in southeast Brazil: do morphometric differences promote life strategies selection? Hydrobiologia, in press.

BEZERRA-NETO, JF. and PINTO-COELHO, RM., 2008. Morphometric study of Lake Dom Helvécio, Parque Estadual do Rio Doce (PERD), Minas Gerais, Brazil: a re-evaluation. Acta Limnologica Brasiliensia, vol. 28, no. 2, p. 161-167.

BICUDO, CEM., 1988. Polymorphism in the desmid Cosmarium abbreviatum var. minus (Zygnemaphyceae) and its taxonomical implications. Acta Botanica Brasílica, vol. 2, no. 1-2, p. 1-6. http://dx.doi.org/10.1590/S0102-33061988000100001.

BICUDO, CEM. and SORMUS, L., 1972. Polymorphism in the desmid Micrasterias laticeps and its taxonomical implications. Journal of Phycology, vol. 8, no. 3, p. 237-242. http://dx.doi. org/10.1111/j.0022-3646.1972.00237.x.

BICUDO, DC., 1990. Considerações sobre metodologias de contagem de algas do perifíton. Acta Limnologica Brasiliensia, vol. 3 , p. $459-475$

BRANDHAM, PE., 1964. Cytology, sexuality and mating type in culture of certain desmids. London: University of London. Ph.D. thesis.

BROOK, AJ., 1959. The status of desmids in the plankton and the determinations of phytoplankton quotients. Journal of Ecology, vol. 47, no. 2, p. 429-445. http://dx.doi.org/10.2307/2257375.

BROOK, AJ., 1981. The biology of desmids. Oxford: Blackwell Scientific Publications. 276 p.

CANTER, HM. and LUND, JWG., 1951. Studies on plankton parasites, 3: examples of the interaction between parasitism and other factors determining the growth of diatoms. Annals of Botany, vol. 15, p. 359-371.

CANTER, HM. and LUND, JWG., 1969. Parasitism of planktonic desmids by fungi. Österreichische Botanische Zeitschrift, vol. 116 , p. $351-377$

COCHE, AG., 1974. Limnological study of a tropical reservoir. In BALON, EK. and COCHE, AG. Lake Kariba: a man-made tropical ecosystem in central Africa. The Hague: Dr. W. Junk Publishers. p. 7-247.

COESEL, PFM., 1994. On the ecological significance of a cellular mucilaginous envelope in planktic desmids. Algological Studies, vol. 73, p. 65-74.

COESEL, PFM., 2001. A method for quantifying conservation value in lentic freshwater habitats using desmids as indicator organisms. Biodiversity and Conservation, vol. 10, no. 2, p. 177187. http://dx.doi.org/10.1023/A:1008985018197.

COESEL, PFM. and KOOIJMAN-VAN BLOKLAND, H., 1991. Seasonality of planktonic desmid species in Lake Maarsseveen (The Netherlands) related to experimentally determined growth rates in a temperature-light gradient. Verhandlungen - Internationale Vereinigung für Theoretische und Angewandte Limnologie, vol. 24, p. $763-767$

COESEL, PFM., KWAKKESTEIN, R. and VERSCHOOR, A., 1978. Oligotrophication and eutrophication tendencies in some Dutch moorland pools, as reflected in their desmid flora. Hydrobiologia, vol. 61, no. 1, p. 21-31. http://dx.doi.org/10.1007/BF00019021.

DE MEIS, MRM. and TUNDISI, JG., 1986. Geomorphological and limnological process as a basis for lake tipology: the middle Rio Doce lake system. Anais da Academia Brasileira de Ciências, vol. 58 , no. 1. p. 103-120

DE MEIS, MRM. and TUNDISI, JG., 1997. Geomorphological and limnological process as a basis for lake tipology. The middle Rio Doce lake system. In TUNDISI, JG. and SAIJO, Y. Limnological studies in the Rio Doce Valley lakes. São Carlos: Academia Brasileira de Ciências. p. 25-50.

FORDYCE, JA., 2006. The evolutionary consequences of ecological interactions mediated through phenotypic plasticity. The Journal of Experimental Biology, vol. 209, no. 12, p. 2377-2383. http:// dx.doi.org/10.1242/jeb.02271. PMid:16731814

HENRY, R. and BARBOSA, FAR., 1989. Thermal structure, heat content and stability of two lakes in the National Park of Rio Doce Valley (Minas Gerais, Brazil). Hydrobiologia, vol. 171, no. 3, p. 189-199. http://dx.doi.org/10.1007/BF00008142.

HOLFELD, H., 1998. Fungal infections of the phytoplankton: seasonality, minimal host density, and specificity in a mesotrophic lake. The New Phytologist, vol. 138, no. 3, p. 507-517. http:// dx.doi.org/10.1046/j.1469-8137.1998.00126.x.

HOLFELD, H., 2000. Relative abundance, rate of increase, and fungal infections of freshwater phytoplankton. Journal of Plankton Research, vol. 22, no. 5, p. 987-995. http://dx.doi.org/10.1093/ plankt/22.5.987.

IDSO, S., 1973. On the concept of lake stability. Limnology and Oceanography, vol. 18 , no. 4, p. 681-683. http://dx.doi. org/10.4319/lo.1973.18.4.0681.

JACOBSEN, BA. and SIMONSEN, P., 1993. Disturbance events affecting phytoplankton biomass, composition and species diversity in a shallow, eutrophic, temperate lake. Hydrobiologia, vol. 249, no. 1-3, p. 9-14. http://dx.doi.org/10.1007/BF00008838.

JENSEN, P., JEPPESEN, E., OLRIK, K. and KRISTENSEN, P., 1994. Impact of nutrients and physical factors on the shift from cyanobacterial to chlorophyte dominance in shallow Danish lakes. Canadian Journal of Fisheries and Aquatic Sciences, vol. 51, no. 8, p. 1692-1699. http://dx.doi.org/10.1139/f94-170.

KAGAMI, M., BRUIN, A., IBELINGS, BW. and VAN DONK, E., 2007. Parasitic chytrids: their effects on phytoplankton 
community and food-web dynamics. Hydrobiologia, vol. 578, no. 1, p. 113-129. http://dx.doi.org/10.1007/s10750-006-0438-z.

KOUWETS, F., 2008. The species concept in desmids: the problem of variability, infraspecific taxa and the monothetic species definition. Biologia, vol. 63, no. 6, p. 881-883. http:// dx.doi.org/10.2478/s11756-008-0135-7.

MORALES, EA., TRAINOR, FR. and SCHLICHTING, CD., 2002. Evolutionary and ecological implications of plastic responses of algae. Constancea, vol. 83, no. 4, p. 1-24. http://ucjeps.berkeley. edu/constancea/83/morales_etal/plasticity.html

NASELLI-FLORES, L. and BARONE, R., 2000. Phytoplankton dynamics and structure: a comparative analysis in natural and manmade water bodies of different trophic state. Hydrobiologia, vol. 438, no. 1/3, p. 65-74. http://dx.doi.org/10.1023/A:1004109912119.

NASELLI-FLORES, L. and BARONE, R., 2007. Pluriannual morphological variability of phytoplankton in a highly productive Mediterranean reservoir (Lake Arancio, Southwestern Sicily). Hydrobiologia, vol. 578, no. 1, p. 87-95. http://dx.doi.org/10.1007/ s10750-006-0436-1.

PADISÁK, J., G.-TÓTH, L. and RAJCZY, M., 1990. Stir-up effect of wind on a more-or-less stratified shallow lake phytoplankton community, Lake Balaton, Hungary. Hydrobiologia, vol. 191, no. 1, p. 249-254. http://dx.doi.org/10.1007/BF00026058.

PLAYFAIR, GI., 1908. Some Sidney desmids. Proceedings of the Linnean Society of New South Wales, vol. 33, no. 3, p. 603-628.

PLAYFAIR, GI., 1910. Polymorphism and life history in the Desmidiaceae. Proceedings of the Linnean Society of New South Wales, vol. 35, no. 2, p. 459-495.

REYNOLDS, CS., 2006. Ecology of phytoplankton. Cambridge: Cambridge University Press. 535 p.
REYNOLDS, CS., 1984. The ecology of freshwater phytoplankton. Cambridge: Cambridge University Press. 365 p.

REYNOLDS, N., 1940. Seasonal variations in Staurastrum paradoxum. The New Phytologist, vol. 39, no. 1, p. 86-89. http:// dx.doi.org/10.1111/j.1469-8137.1940.tb07124.x.

SCHEINER, SM., 1998. The genetics of phenotypic plasticity VII. Evolution in a spatially-structured environmental. Journal of Evolutive Biology, vol. 11, no. 3, p. 303-320. http://dx.doi. org/10.1046/j.1420-9101.1998.11030303.x.

SEN, B., 1988. Fungal parasitism of planktonic algae in Shearwater. VI. Parasitic occurrence of a new chytrid species on the blue-green alga Microcystis aeruginosa Kuetz emend. Elenkin. Archiv fuer Hydrobiologie, vol. 79, sup. Suppl, p. 177-184.

STOYNEVA, MP., DESCY, JP. and VYVERMAN, W., 2007. Green algae in Lake Tanganyika: Is morphological variation a response to seasonal changes? Hydrobiologia, vol. 578, no. 1, p. 7-16. http://dx.doi.org/10.1007/s10750-006-0428-1.

TUNDISI, JG. and MUSSARRA, ML., 1986. Morphometry of four lakes in the Rio Doce Valley System and its relationship with primary production of phytoplankton. Revista Brasileira de Biologia =. Brazilian Journal of Biology, vol. 46, no. 1, p. 159-171.

VAN DONK, E. and RINGELBERG, J., 1983. The effect of fungal parasitism on the succession of diatoms in Lake Maarsseveen I (The Netherlands). Freshwater Biology, vol. 13, no. 3, p. 241-251. http://dx.doi.org/10.1111/j.1365-2427.1983.tb00674.x.

WILTSHIRE, K., BOERSMA, M. and MEYER, B., 2003. Grazerindiced changes in desmid Staurastrum. Hydrobiologia, vol. 491, no. 1-3, p. 255-260. http://dx.doi.org/10.1023/A:1024474827107. 